International Journal of Advanced Trends in Computer Science and Engineering

Available Online at http://www.warse.org/IJATCSE/static/pdf/file/ijatcse303942020.pdf

https://doi.org/10.30534/ijatcse/2020/303942020

\title{
Identification of violent behavior using Handwriting
}

\author{
Deepti Jain ${ }^{1}$, Dr. Sandhya Arora ${ }^{2}$, Dr. C.K. Jha ${ }^{3}$ \\ ${ }^{1}$ Department of Computer Science, AIM \& ACT, Banasthali Vidyapith, Banasthali 304022, India, \\ deepti.kheterpal@gmail.com \\ ${ }^{2}$ Department of Computer Science, Cummins College of Engineering, Pune 411058, India, \\ sandhya.arora02@gmail.com \\ ${ }^{3}$ Department of Computer Science, AIM \& ACT, Banasthali Vidyapith, Banasthali 304022, India, \\ ckjha1@gmail.com
}

\begin{abstract}
Violent behavior in one's personality is hidden aspect as it has some roots in writer's subcoscious and is reflected in one's handwriting. Identifying violent behavior has its importance as it is closely related with personality disorders and its associated crimes. Identifying violence behavior in handwriting is crucial as it can prohibit future crimes. Graphology or handwriting analysis is a scientific method to identify, evaluate and understand the personality of an individual through patterns revealed by handwriting. Handwriting analysis is done by skilled graphologists however, with the advancement of technology we are able to facilitate the task of human specialists by processing handwritten images. This paper proposes a novel approach to identify violent and aggressive behavior through handwriting. The aim of this research is to study and examine the relationship between handwriting and violent behavior. The graphic handwriting characteristics of total 60 samples, were taken for the study including 30 for normal and 30 for violent handwriting samples. The samples of violent handwriting were analyzed and compared with normal handwriting samples. Some potential features in handwriting were found which were useful to identify violent and aggressive behavior.
\end{abstract}

Key words: handwriting analysis, image analysis, violent behavior.

\section{INTRODUCTION}

Today crime rates are increasing at a rapid rate. Social media, news and other sources presents new information every day along with unique crime cases which are violent and highly aggressive in nature. There are many crime cases to be considered but the most famous, violent crime cases in India was 2014 Delhi gang rape case in which the girl was brutally raped and four accused involved in the gang rape did some disgraceful violent actions which cannot be even described here[1]. Another highlighted case was of Ryan International School Crime in which class two student was murdered by class eleven student to postpone class exams. Studies reveal the fact that no one could even imagine the violent and aggressive behavior because the accused was calm and composed and was famous in school for playing musical instrument [2]. Joanna Dennehy, a 31-year-old British woman killed three men in 2013[3] and the most famous American serial killer Ted Bundy murdered 30 people in his life span [4].

What is common behavior in these criminals is their aggressive and violent nature behind their cool and calm exterior. Their sudden aggression and violent nature are very different from normal people that leads them doing these brutal crimes[5]. Due to this difference they fall into the category of personality disordered people[6][7]. People whose crimes are violent and very aggressive are psychopathic/anti-social in nature[7][8]. Till now, Personality disorders are studied from two perspectives. Major studies are done from psychological and psychiatric aspects [8][9]. To study personality disorder from psychological perspective psychologists concentrate on behavior aspects and this is done by set of lengthy structured interviews, however psychiatry study personality disorders based on mental feature like amygdale, fMRI etc. [10]. Graphology is still untouched to study personality disorders. Graphology is the scientific study of handwriting to determine personality traits, psychological states temperament or the behavior of the writer [11]. From centuries handwriting has been used by humans as a way to express and communicate but recently its links to the psychological aspects of human, and brain activity has been studied [12].

Study by Plamondon[13] reveals that based on habits of writers the brain forms characters and respective neurological brain pattern is characterized by a distinctive neuromuscular movement. Handwriting is an important human feature that comes directly from brain like all other actions. Brain drive writing instrument(hand) to write (Hayes, 1993). The writing organ is controlled by central nervous system making the writing process unconscious, yet most revealing (Nezos 1986:5). Handwriting is closely related to brain impulses and reveal information about a person's mood emotions and 
mental health (Branston 1998, Hayes 1993). It is used as a tool by forensic graphologists to study criminal personality and can assist in criminal investigation [14]. Research by [15] from psychopath paper] shows that people having psychopathic personality disorder have dysfunctional amygdale and it is reflected in their handwriting [16]. Some researches [65] did crime analysis using Apriori Algorithm. Due to the advancement of technology handwriting analysis is done with the help of computers and it is used extensively in various applications. Numerous studies considered handwriting as a biometric behavior and due to this it can be considered as an identification tool[17]. There is lot of research available to predict personality characteristics using handwriting [3, 5,9,7-14]however the research to identify violent behavior in handwriting is scanty. According to studies conducted by[14] states that extremely larger alphabets in handwriting sample should be considered as red flag. People with large handwriting has inflated vision of own importance[18]. Only single research is available[19] that analyses violent and aggressive behavior in the psychopath's handwriting (personality disordered person). This feature requires further research, thus in this paper we have taken handwriting as one of the important features to study violent behavior. This paper focuses on identifying red flags in handwriting that may lead to violent behavior in later stage. We believe that by studying violent and aggressive traits in handwriting can assist in the diagnose psychopathic/antisocial personality disorder, thus it can be of great help for the society.

Our methodology is thoroughly explained in Figure 2. The rest of the paper is organized as follows; Section 2 presents related literature. We then discuss signs of danger in graphology 3. In Section 4 we discuss the proposed architecture and algorithm in detail. Discussion of simulation results, observations, its applicability and limitations are presented in section 5 and Section 6 concludes the paper with future research.

\section{RELATED WORK}

Majority of handwriting analysis is focused on finding personality traits \& behavior and is done by graphologists thorough set of questionnaires and reviewing its results. Here state-of-art research is presented in this area along with several studies which determine mental status, psychological traits, personality types and behavior of individuals with the help of handwriting in Table1, Table 2. 
Deepti Jain et al., International Journal of Advanced Trends in Computer Science and Engineering, 9(4), July - August 2020 , 6238 - 6250

Table 1: Related work

\begin{tabular}{|c|c|c|c|c|}
\hline $\begin{array}{l}\text { Paper } \\
\text { Title }\end{array}$ & Aim & Technique Applied & Features Extracted & Results \\
\hline [20] & $\begin{array}{l}\text { A Machine Learning Approach to Employability } \\
\text { Evaluation Using Handwriting Analysis }\end{array}$ & $\begin{array}{l}\text { Naïve Bayes, Random } \\
\text { Forest and Support Vector } \\
\text { Machine }\end{array}$ & $\begin{array}{l}\text { margin, baseline, letter size, } t \\
\text { characteristics and the applied } \\
\text { pen pressure. }\end{array}$ & $\begin{array}{l}\text { The employer can discern the } \\
\text { traits of the interviewee which } \\
\text { may not have been apparent } \\
\text { otherwise }\end{array}$ \\
\hline [21] & $\begin{array}{l}\text { Personality Detection using Handwriting } \\
\text { Analysis: Review }\end{array}$ & $\begin{array}{l}\text { Handwriting analysis } \\
\text { System using various } \\
\text { features like slant, baseline, } \\
\text { size, spacing and margin }\end{array}$ & $\begin{array}{l}\text { baseline, size, slant, spacing, } \\
\text { margin, pressure etc. and a } \\
\text { greater number of features } \\
\text { like zone, } \mathrm{f}, \mathrm{i} \text {, speed of } \\
\text { handwriting }\end{array}$ & $\begin{array}{l}\text { Successfully identified } \\
\text { personality of a person using } \\
\text { HAS. }\end{array}$ \\
\hline [22] & $\begin{array}{l}\text { Handwriting Analysis for Detection of } \\
\text { Personality Traits using Machine Learning } \\
\text { Approach }\end{array}$ & K-NN classifier & $\begin{array}{l}\text { Polygonization for baseline, } \\
\text { margin will be calculated } \\
\text { using the method of vertical } \\
\text { scanning. }\end{array}$ & $\begin{array}{l}\text { It will also assist the } \\
\text { HR/company employer in } \\
\text { decision making. }\end{array}$ \\
\hline [23] & $\begin{array}{l}\text { A Comprehensive Survey on Handwriting and } \\
\text { Computerized Graphology }\end{array}$ & Diff techniques discussed & $\begin{array}{l}\text { Various features in different } \\
\text { papers }\end{array}$ & $\begin{array}{l}\text { Survey of handwriting and } \\
\text { computerized graphology }\end{array}$ \\
\hline [24] & $\begin{array}{l}\text { An Algorithm to Extract Handwriting Feature for } \\
\text { Personality Analysis }\end{array}$ & $\begin{array}{l}\text { Image Processing was used } \\
\text { for feature extraction using } \\
\text { MATLAB. }\end{array}$ & Tittle over letter i. & $\begin{array}{l}\text { help identifying those people } \\
\text { who are emotionally } \\
\text { disturbed or depressed and } \\
\text { need psychological help to } \\
\text { overcome such negative } \\
\text { emotions. }\end{array}$ \\
\hline [25] & $\begin{array}{l}\text { Human Behavioral Analysis Based on } \\
\text { Handwriting Recognition and Text Processing }\end{array}$ & $\begin{array}{l}\text { Matlab, TOPOCR, RAPID } \\
\text { MINOR }\end{array}$ & $\begin{array}{l}\text { four parameters: pressure, } \\
\text { slant, baseline, and } \\
\text { dimension. }\end{array}$ & $\begin{array}{l}\text { Successful in predicting } \\
\text { human behavior }\end{array}$ \\
\hline [26] & $\begin{array}{l}\text { Perception Based Decision Support System for } \\
\text { Handwriting Behavior Analysis }\end{array}$ & $\begin{array}{l}\text { The MANOVA was } \\
\text { performed using IBM-SPSS } \\
\text { ver. } 22.0\end{array}$ & $\begin{array}{l}\text { pressure, temporal (stroke } \\
\text { duration on digitizer and in } \\
\text { air) and spatial measures }\end{array}$ & $\begin{array}{l}\text { spatio-temporal features } \\
\text { extracted which showed } \\
\text { significant differences in true } \\
\text { and distorted cases. }\end{array}$ \\
\hline [27] & $\begin{array}{l}\text { Identification of Personality Trait by } \\
\text { Handwriting Analysis Using SVM Classifier }\end{array}$ & SVM & $\begin{array}{l}\text { spacing between words and } \\
\text { characters }\end{array}$ & $\begin{array}{l}\text { The classifier SVM is being } \\
\text { used. } 90 \% \text { accuracy is } \\
\text { achieved. }\end{array}$ \\
\hline [28] & $\begin{array}{l}\text { Detecting features of human personality based on } \\
\text { handwriting using learning algorithms }\end{array}$ & $\begin{array}{l}\text { Feature Vector and } \\
\text { Generalized Discriminant } \\
\text { Analysis (GDA), Matlab }\end{array}$ & $\begin{array}{l}\text { Line tilt, word extension, } \\
\text { word space, line space, word } \\
\text { tilt, margin of the first page, } \\
\text { character size }\end{array}$ & $\begin{array}{l}\text { Learning algorithm was able } \\
\text { to predict features of human } \\
\text { personality. }\end{array}$ \\
\hline [29] & $\begin{array}{l}\text { Human Behavior prediction through handwriting } \\
\text { using BPN }\end{array}$ & BPN & Alignment and Thickness & $\begin{array}{l}\text { terms of each letter, obtained } \\
\text { recognition accuracy of } 56 \% \text {. }\end{array}$ \\
\hline [30] & $\begin{array}{l}\text { Handwriting Analysis Based Human Personality } \\
\text { Prediction Using Sugeno Fuzzy Model }\end{array}$ & $\begin{array}{l}\text { Sugeno based fuzzy system } \\
\text { designed using MATLAB }\end{array}$ & $\begin{array}{l}\text { spacing, size, slant, shape, } \\
\text { loop, dot, pressure, signature, } \\
\text { zones and page margin. }\end{array}$ & $\begin{array}{l}\text { Performance of the model has } \\
\text { been evaluated using mean } \\
\text { square error (MSE) and root } \\
\text { mean square error (RMSE). }\end{array}$ \\
\hline [31] & $\begin{array}{l}\text { Handwritten Text Recognition using Deep } \\
\text { Learning...project }\end{array}$ & $\begin{array}{l}\text { Convolutional Neural } \\
\text { Network (CNN) }\end{array}$ & $\begin{array}{l}\text { classifying words directly and } \\
\text { character segmentation }\end{array}$ & $\begin{array}{l}\mathrm{CNN} \text { found accurate results } \\
\text { for recognizing handwritten } \\
\text { text. }\end{array}$ \\
\hline [32] & $\begin{array}{l}\text { An Empirical Study on Writer Identification \& } \\
\text { Verification from Intra-variable Individual } \\
\text { Handwriting }\end{array}$ & $\begin{array}{l}\text { SVM and Convolutional } \\
\text { Neural Network (CNN) }\end{array}$ & $\begin{array}{l}\text { Macro-Micro features, } \\
\text { Contour direction and hinge } \\
\text { level features, Direction and } \\
\text { curvature features at } \\
\text { key-points. }\end{array}$ & $\begin{array}{l}\text { It was noted that the } \\
\text { state-of-the-art methods do } \\
\text { not perform well. }\end{array}$ \\
\hline [9] & $\begin{array}{l}\text { Writer identification using machine learning } \\
\text { approaches: a comprehensive review }\end{array}$ & Review Paper & $\begin{array}{l}\text { Multi script features with } \\
\text { deep learning approach }\end{array}$ & $\begin{array}{l}\text { Writer identification can be } \\
\text { applicable in forensic, } \\
\text { historical and handwriting } \\
\text { analysis }\end{array}$ \\
\hline [33] & $\begin{array}{l}\text { Identifying Personality Traits, and Especially } \\
\text { Traits Resulting in Violent Behavior through } \\
\text { Automatic Handwriting Analysis }\end{array}$ & $\begin{array}{l}\text { Different softwares like } \\
\text { WANDA and MoValyzer, } \\
\text { Foster and freeman, }\end{array}$ & $\begin{array}{l}\text { Lewinson-Zubin scale was } \\
\text { described. Handedness, } \\
\text { education, was described. }\end{array}$ & $\begin{array}{l}\text { Different characteristics were } \\
\text { uncovered related to violent } \\
\text { and non-violent were } \\
\text { explored. }\end{array}$ \\
\hline [34] & $\begin{array}{l}\text { Automated Prediction of Human Behavior } \\
\text { System for Career Counselling of an } \\
\text { Individual through Handwriting Analysis / }\end{array}$ & $\overline{\mathrm{ANN}}$ & $\begin{array}{l}\text { size, slant, word spacing, pen } \\
\text { pressure, line } \\
\text { spacing, upper zone loops. }\end{array}$ & $\begin{array}{l}\text { Algorithm designed for letter } \\
\text { and for words to extract } \\
\text { features }\end{array}$ \\
\hline [35] & $\begin{array}{l}\text { Human Character Recognition by Handwriting } \\
\text { using Fuzzy Logic }\end{array}$ & ANN using Matlab & Only design arch is given & $\begin{array}{l}\text { Architecture shows character } \\
\text { recognition by fuzzy logic }\end{array}$ \\
\hline
\end{tabular}


Deepti Jain et al., International Journal of Advanced Trends in Computer Science and Engineering, 9(4), July - August 2020,6238 - 6250

Table 2: Related work

\begin{tabular}{|c|c|c|c|c|}
\hline Paper Title & Aim & Technique Applied & Features Extracted & Results \\
\hline [36] & $\begin{array}{l}\text { Off-line Text-independent Writer } \\
\text { Identification Using Local } \\
\text { Convex Micro-Structure Patterns }\end{array}$ & $\begin{array}{l}\text { Local Convex } \\
\text { Micro-Structure Patterns } \\
\text { (LCxMSP) descriptor and } \\
1 \text { NN (Nearest Neighbor) } \\
\text { classifier and ICDAR2011 } \\
\text { database }\end{array}$ & $\begin{array}{l}\text { Traditional Local Binary } \\
\text { Patterns and Local Convex } \\
\text { Micro-Structure Patterns }\end{array}$ & $\begin{array}{l}\text { To identify and characterize } \\
\text { the query writers, proposed } \\
\text { framework demonstrated } \\
\text { superior Performance from } \\
\text { ICDAR2011 database. }\end{array}$ \\
\hline [28] & $\begin{array}{l}\text { Detecting features of human personality } \\
\text { based on } \\
\text { handwriting using learning algorithms }\end{array}$ & $\begin{array}{l}\text { MMPI personality test and } \\
\text { neural network }\end{array}$ & $\begin{array}{l}\text { Using dependent and } \\
\text { Independent features of text } \\
\text { like } \\
\text { word expansion, } \\
\text { characters sizes, line spaces, } \\
\text { word spaces etc. }\end{array}$ & $\begin{array}{l}\text { Proposed method achieved } \\
76 \% \text { efficiency }\end{array}$ \\
\hline [37] & $\begin{array}{l}\text { Personality Trait Identification Using } \\
\text { Unconstrained Cursive and Mood } \\
\text { Invariant Handwritten Text }\end{array}$ & SVM and ANN & $\begin{array}{l}\text { Up-Hill Line } \\
\text { Down-Hill Line } \\
\text { Constant line }\end{array}$ & $\begin{array}{l}\text { The results were about } 98 \% \\
\text { for SVM \& 70\% with ANN. } \\
\text { The analysis was done using } \\
\text { single line }\end{array}$ \\
\hline [10] & $\begin{array}{l}\text { Detection of Deception Via Handwriting } \\
\text { Behaviors Using a Computerized } \\
\text { Tool: Toward an Evaluation of } \\
\text { Malingering }\end{array}$ & $\begin{array}{l}\text { The sociodemographic } \\
\text { questionnaire and } \\
\text { Computerized Penmanship } \\
\text { Evaluation Tool } \\
\text { (ComPET), MATLAB }\end{array}$ & $\begin{array}{l}\text { Temporal measures, stroke } \\
\text { path length, stroke height, } \\
\text { stroke width, angular velocity } \\
\text { of the stroke }\end{array}$ & $\begin{array}{l}\text { Results confirm that } \\
\text { handwriting measures are } \\
\text { sensitive } \\
\text { to deceptive writing, and are } \\
\text { aligned with previous } \\
\text { results. }\end{array}$ \\
\hline [38] & $\begin{array}{l}\text { Measuring the Frequency Occurrence of } \\
\text { Handwriting and Hand-Printing } \\
\text { Characteristics }\end{array}$ & $\begin{array}{l}\text { Attribute Agreement } \\
\text { Analysis (AAA) is a } \\
\text { statistical method }\end{array}$ & $\begin{array}{l}\text { multiple } \\
\text { characteristics of letters } \\
\text { (cursive and hand printed), } \\
\text { numbers and punctuation } \\
\text { marks }\end{array}$ & $\begin{array}{l}\text { Statistical studies in this } \\
\text { report have concluded as to } \\
\text { the very high degree of } \\
\text { independence of cursive and } \\
\text { hand printed entries }\end{array}$ \\
\hline [14] & $\begin{array}{l}\text { Forensic Analysis of Handwritten } \\
\text { Documents with GRAPHJ }\end{array}$ & GRAPHJ & $\begin{array}{l}\text { text lines and words in the } \\
\text { document; specific character } \\
\text { and detect its occurrences in } \\
\text { the handwritten text. }\end{array}$ & $\begin{array}{l}\text { GRAPHJ can be effectively } \\
\text { used to perform the analysis of } \\
\text { handwritten documents. }\end{array}$ \\
\hline [33] & $\begin{array}{l}\text { Identifying Personality Traits, and } \\
\text { Especially Traits Resulting in Violent } \\
\text { Behavior through Automatic } \\
\text { Handwriting Analysis }\end{array}$ & $\begin{array}{l}\text { NEURO SCRIPT, } \\
\text { WANDA, CEDAR-FOX, } \\
\text { and Gaussian Mixture } \\
\text { Model. }\end{array}$ & $\begin{array}{l}\text { Incline (slant to the left or } \\
\text { right) } \\
\text { 2. Shape (evenness of letter } \\
\text { size) } \\
\text { 3. Form (roundness }\end{array}$ & $\begin{array}{l}\text { The comparisons were helpful } \\
\text { in determining if an individual } \\
\text { had the potential to further } \\
\text { commit violent crimes. }\end{array}$ \\
\hline [39] & $\begin{array}{l}\text { Statistical Examination of Handwriting } \\
\text { Characteristics using } \\
\text { Automated Tools }\end{array}$ & $\begin{array}{l}\text { PGMs (Bayesian networks) } \\
\text { and undirected PGMs } \\
\text { (Markov networks) } \\
\text { Probability of random } \\
\text { correspondence (PRC) }\end{array}$ & $\begin{array}{l}\text { QD Examiner determined } \\
\text { characteristics, automatically } \\
\text { determined characteristics. }\end{array}$ & $\begin{array}{l}\text { Correct classification of an } \\
\text { average of } 94.5 \% \text {. }\end{array}$ \\
\hline [40] & $\begin{array}{l}\text { Detecting Honest People's Lies in } \\
\text { Handwriting: The Power of the Ten } \\
\text { Commandments and Internalized } \\
\text { Ethical Values }\end{array}$ & $\begin{array}{l}\text { Theoretical Model of } \\
\text { Communication and } \\
\text { Detecting } \\
\text { Lies like "Decoding" }\end{array}$ & $\begin{array}{l}\text { Left margin, right margin, pen } \\
\text { pressure, context }\end{array}$ & $\begin{array}{l}\text { Executives and educators can } \\
\text { easily learn the tacit } \\
\text { knowledge, skills to detect } \\
\text { lies. }\end{array}$ \\
\hline [41] & Individuality of Handwriting & $\begin{array}{l}\text { Software } \\
\text { tools such as FISH (Forensic } \\
\text { Information System for } \\
\text { Handwrit } \\
\text { ing) }\end{array}$ & $\begin{array}{l}\text { Micro features like line } \\
\text { separation, slant, character } \\
\text { shapes etc. and Macro } \\
\text { features like darkness } \\
\text { features, contour features, } \\
\text { grey level threshold etc. }\end{array}$ & $\begin{array}{l}\text { They were able to validate } \\
\text { handwriting individuality } \\
\text { with } \\
\text { a 95\% confidence with } \\
\text { promise of aiding the FDE } \\
\text { (Forest Document } \\
\text { Examination. }\end{array}$ \\
\hline [19] & $\begin{array}{l}\text { The writing of criminal minds, } \\
\text { criminology and handwriting analysis }\end{array}$ & $\begin{array}{l}\text { Graphology and } \\
\text { graphopathology }\end{array}$ & $\begin{array}{l}\text { Writing zones, rightward } \\
\text { slant, blurred. }\end{array}$ & $\begin{array}{l}\text { Along with graphology, } \\
\text { scientific instruments need to } \\
\text { be added. }\end{array}$ \\
\hline [42] & $\begin{array}{l}\text { Predicting the Big Five personality traits } \\
\text { from handwriting }\end{array}$ & FMM and Graphology A & $\begin{array}{l}\text { Baseline, Writing pressure, } \\
\text { lowercase " } \mathrm{t} \text { " feature, } \\
\text { lowercase "f" feature }\end{array}$ & $\begin{array}{l}\text { Prediction accuracy is around } \\
77 \% \text {. }\end{array}$ \\
\hline
\end{tabular}


Research in the area of computer science community focused majorly on prediction personality types with the help of machine learning techniques as mentioned above. But research related to identify violent and aggressive behavior in handwriting is scanty. In this paper we have focused on identifying violent behavior and sign of aggressiveness in handwriting. Studying signs of violent behavior and dangerousness in handwriting is very crucial.

\section{GRAPHOLOGICAL ANALYSIS AND SIGNS OF DANGEROUSNESS}

Handwriting has measurable features that which is able to describe writers [43]. Numerous studies have accepted handwriting as a biometric behavior to be used as an identification tool. [13, 46][1, 4-8] In computer science, finding an automated approach to analyze handwriting has vital merit for forensics, biometrics, library science, and data science[17] Typically, to analyze the handwriting of an individual, graphologists look for a specific set of features, each of them convey a specific message[45]. There is comprehensive list of features that are studied by the graphologists, which is not possible in a single study, however some very important and potential features describing aggressive and violent behavior is primarily studied in our research. Some of these features are discussed in this section. The most potential feature for aggressive behavior is OVERLY WIDE SPACES BETWEEN WORDS. The abnormal distance between words indicates paranoia. since the person cannot get close to other persons. The distance you put in each word represents the distance you maintain between you and the other people. People having abnormal distance in words in their handwritings tend to be apprehensive of the motives intentions of others and are suspicious. They feel the need to control everyone, failing this leads to aggression in them. That is why they are paranoid[12][46]. There is hardly any trust in others. They cannot become intimate with others. Their life will be marked with lack of intimacy[46][47]. Along with wide spaces between words word HEIGHT is very important feature to study violence in one's nature. Extreme larger alphabets specially the UPPER ZONE indicates demanding conscience. On the other hand, CLOSELY SPACED LETTERS and OVERLYSPACED LETTERS indicates that these individuals suffer from two negative aspects. The distance maintained between letters and their closely spaced letters indicate that they are uptight. This confirms their paranoid nature. These individuals have real social problems are they are socially maladjusted. Upper loops that come to a point indicates anger, frustration, tension, worry and anxiety[47][12]. SOCIOPATHIC BASELINE (INCOHERENT BASELINE) is also indication of aggression in one's personality. People with incoherent baseline has difficulty to maintain a coherent spatial pattern, thus does not fit to stay within any kind of pattern or line of society. Anyone who disregards the societal norms and don not want to be part of society norms tends to be a sociopath. The rules of the society do not matter to him/her [48]. Next important feature to consider for studying violent behavior is uneven HEAVY PRESSURE, slashing angry strokes UNEVEN SLANT AND BASELINE. Heavy pressure with heaviness accompanied by extreme angularity is an indicator of aggression and violent tendencies [12,50]. Other negative features associated with angular handwriting are hardness, tenseness and sharpness, lack of compromise, cruelty and sadism. Forcing them to change leads them to violent behavior and aggressive acts. Anything twisted, and deformed in handwriting is a symptom of twisted, and aberrant thinking. This person is potentially dangerous, because he/she is crooked, distorted, and twisted in thinking [12]. DISCONNECTED WRITING also linked to isolation and withdrawal and people are not able to link experiences with life and develop violent tendencies. The summed-up features with graphics indices of expression can be seen in Figure1., signs of dangerousness and signs of dishonesty can be seen in Figure 2 and Figure 3.

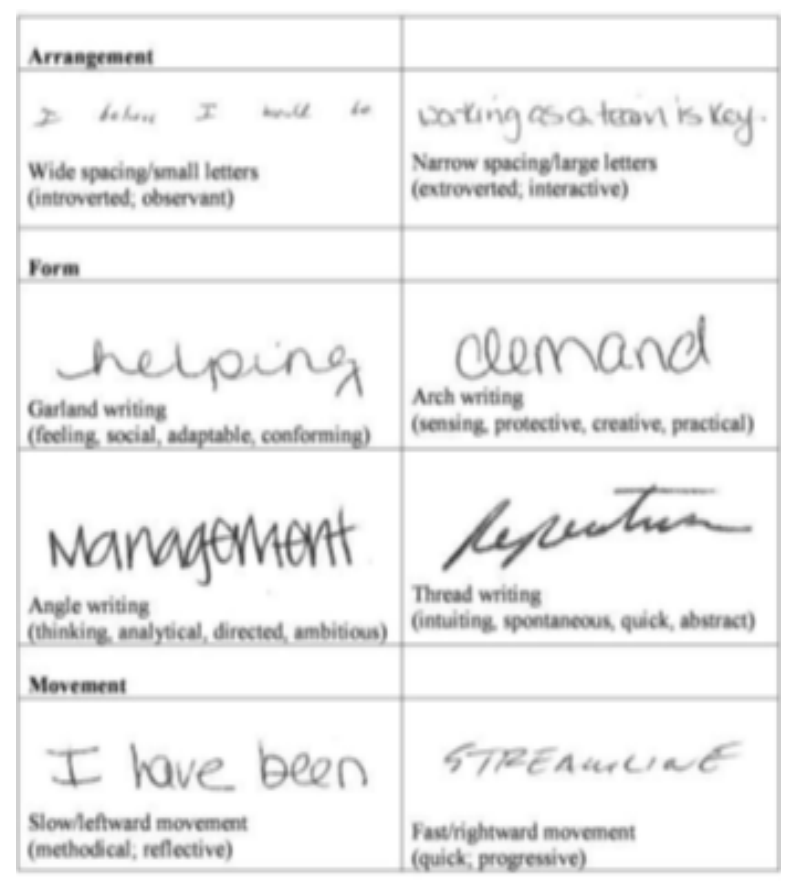

Figure 1: Graphic indices of expression

According to report published by East Tennessee University there are handwriting which contains signs of dangerousness. The list of these signs is explained in Figure 2. Research by[6] states that by studying handwriting signs of dangerousness is closely related to personality disorder. Figure 3. lists handwriting features that show signs of dishonesty. Along with handwriting analysis personality disorders can also be identified by speech patterns [63]. 


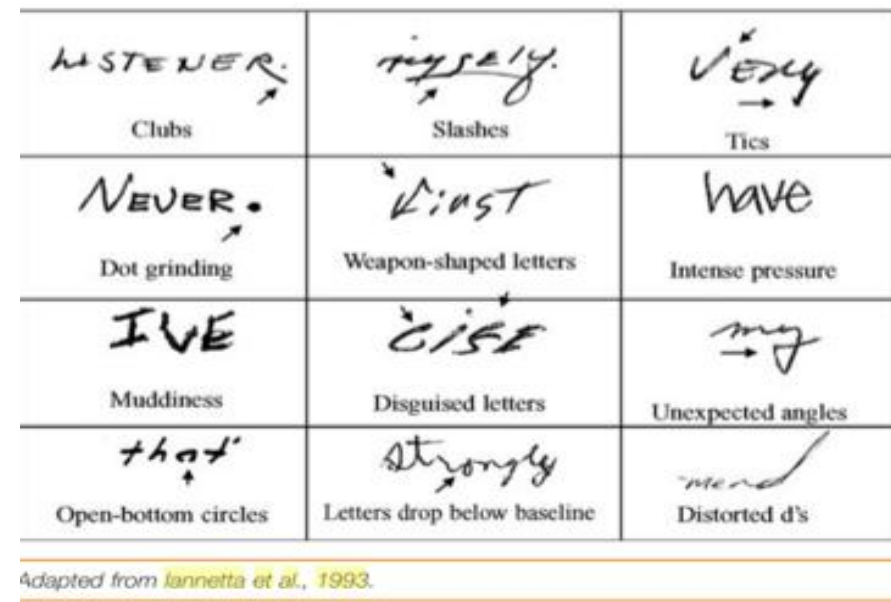

Figure 2: Handwriting signs of Dangerousness.



Figure 3: Handwriting signs of Dishonesty (Saudek,1978),

\section{FEATURE SELECTION AND PROPOSED ALGORITHM}

Handwriting has some significant features that which helps to distinguish writers [49]. To find an automated approach to analyze handwriting has vital merit for biometrics, forensics, data science etc. Automated approach to analyze handwriting with the help of machine learning techniques has gained popularity among research community recently. Different researches have taken features to predict personality by analyzing their handwriting however very few of them have taken into consideration one's hidden aspect of the personality like violent nature and signs of aggression in one's personality. The main handwriting features used and the ones that we explore in the current paper to study violence and aggression in one's persona are the following: baseline, space between lines, writing pressure, word slant and connecting strokes. Examples of each of these features and their types as explained in [11] can be observed in Table 3.
Table 3: Features Extracted

\begin{tabular}{|c|c|c|}
\hline $\begin{array}{l}\text { The name of the } \\
\text { graphical } \\
\text { properties }\end{array}$ & $\begin{array}{l}\text { Description } \\
\text { (Holyst, 2004) }\end{array}$ & $\begin{array}{l}\text { Indicator (all are } \\
\text { numerical } \\
\text { variables) }\end{array}$ \\
\hline Letter Size & $\begin{array}{l}\text {-Small size letters: } \\
\text { lowercase } \\
\text { letter height is less } \\
\text { than } 2.5 \mathrm{~mm} \text {; } \\
\text { - Medium size } \\
\text { letters: lowercase } \\
\text { Letters height is } \\
\text { between } 2.6 \mathrm{~mm} \text { and } \\
4 \mathrm{~mm} \text {; } \\
\text { - Large size letters: } \\
\text { lowercase } \\
\text { Letter height is over } \\
4 \mathrm{~mm} \text {. }\end{array}$ & $\begin{array}{l}\text { Indicates the } \\
\text { number of letters of } \\
\text { each size in the text }\end{array}$ \\
\hline $\begin{array}{l}\text { Letter } \\
\text { Connectivity }\end{array}$ & $\begin{array}{l}\text { Connectivity types } \\
\text { between } \\
\text { the letters in a word: } \\
\text { - syllable (without } \\
\text { giving } \\
\text { pause } \\
\text { two/three/four } \\
\text { letters } \\
\text { are written) } \\
\text { - phrase (phrase } \\
\text { constitute of } \\
\text { connected words) } \\
\text {-- word (word } \\
\text { written without } \\
\text { pause); } \\
\text { - letter (each letter is } \\
\text { separately } \\
\text { written in a word); }\end{array}$ & $\begin{array}{l}\text { Indicates the } \\
\text { number of words } \\
\text { written in each type } \\
\text { of } \\
\text { connectivity in the } \\
\text { text }\end{array}$ \\
\hline $\begin{array}{l}\text { Baseline } \\
\text { Direction }\end{array}$ & $\begin{array}{l}\text { Possible directions } \\
\text { of the basic } \\
\text { Line (sinusoidal, } \\
\text { horizontal } \\
\text { Descending). } \\
\end{array}$ & $\begin{array}{l}\text { Indicates the } \\
\text { number of lines of } \\
\text { each type of } \\
\text { direction }\end{array}$ \\
\hline $\begin{array}{l}\text { Three letter } \\
\text { Zone Size }\end{array}$ & $\begin{array}{l}\text { Three zones of } \\
\text { letters (height of } \\
\text { the lower, middle, } \\
\text { and upper } \\
\text { zones measured in } \\
\mathrm{mm} \text { ). }\end{array}$ & $\begin{array}{l}\text { Indicates the } \\
\text { average height of } \\
\text { each } \\
\text { zone given in } \\
\text { millimeters } \\
\text { in the text }\end{array}$ \\
\hline Letters Slant & $\begin{array}{l}\text { Slant of the } \\
\text { handwriting: left, } \\
\text { right, mixed (right } \\
\text { and straight, left } \\
\text { and straight, left and } \\
\text { right, } \\
\text { left right and } \\
\text { straight) }\end{array}$ & $\begin{array}{l}\text { Indicates the } \\
\text { number of words } \\
\text { written in each type } \\
\text { of } \\
\text { slant in the text }\end{array}$ \\
\hline
\end{tabular}

\subsection{Image Feature Extraction Technique}

To extract the desired features that lead to violent and aggressive behavior, image analysis is required. Image analysis involves the basic steps to convert features and objects in image data to into quantitative Information. As images acquired are often noisy, complex, artifact-laden thus it requires multiple image processing steps to extract meaningful quantitative information. An outline for the procedure of image analysis is presented in the following steps 
Normalization: The image is read in the first step as the acquired digital image have imperfections in the image acquisition step like uneven illumination, noise at low light levels, defective pixels etc. thus image pre-processing is required to correct such defects. To accentuate features of interest in the image, image contrast needs to be enhanced. For this spatial filtering and various image transformation techniques are used. Second step is pre-processing in which image is converted to gray scale. After that bitwise not operation is performed which changes black pixels to white and vice versa.

Noise reduction: To remove the noise added by the scanned image which contains unwanted points or lines disconnected strokes that typically cause distortion three filters are used also image was slightly blurred which is followed by performing thresh holding operation. As Boolean filters outperform over other morphological methods, they are used for removing the textured background. They are better in terms of processing time\& accuracy. Ramp width reduction filter is used for edge sharpening. For contrast enhancement Adaptive unsharp masking is employed to adjust the contrast as it is widely used method.

Contour smoothing: In order to reduce the possible errors in the handwriting optimal local weighted averaging method is used to filter out the glitches and only relevant strokes are kept for our analysis. This algorithm is opted as opposed to other less complex local weighted averaging methods because this method is known to provide accurate estimations of tangent slopes, contour point positions and deviation angles as they are essential for handwriting analysis. Also, contours are identified in this step. According to[50]alphabets of medium handwriting should lie between 2.5 to $3.5 \mathrm{~mm}$. To maintain standard for all image's contours between height 5 and 50 were selected. Then we calculated height of each contour, and thus average height of letters in image is retrieved.

Compression: To convert color images to binary global thresholding is used. In order to determine the global threshold, we used the histogram modified by integral ratio value. This was chosen as it provides better performance as compared to other compression techniques. As we require only handwritten for handwriting analysis, we used white space thinning method because it is fast and simple method.

Row segmentation: For row segmentation, we required best classification accuracy thus we used Vertical Projection Profile (VPP) method. After that sum of pixels were analyzed for each row in the image. To determine row boundaries those highest pixels sum is calculated and those with a sum lower than $7.5 \%$ of the highest pixel value is considered. Trial and error method were chosen for threshold of $7.5 \%$. The test was conducted on handwriting samples using leave-one-out approach and the average accuracy of $97.2 \%$ was found for correct row segmentation. By following this step, a corresponding bounding rectangle was made in every row of the handwritten text.

Spacing between lines feature: The amount of overlap between two consecutive rows is determined by the bounding rectangles delimiting each row. The rows are considered to be crowded together, if the overlap is higher than $12 \%$ of the sum of both row bounding rectangles' surfaces, otherwise, they are considered evenly spaced. The $12 \%$ threshold was taken to ensure accurate classification of the handwriting feature.

Baseline feature: In order to determine the baseline features for each row, the method discussed in [51] where the pixel density of each segmented row rectangle is studied and rectangle is rotated within the $-31^{\circ}$ and $+31^{\circ}$ angle thresholds. This is done repeatedly until the highest pixel density is horizontally centered. As this method offers faster convergence and higher classification accuracy as compared to other state-of-the-art methods, it is broadly used for baseline feature extraction. To align the highest pixel density horizontally, rotation within $\left[-6^{\circ} ;+6^{\circ}\right]$ is considered. If it is within $\left[-31^{\circ} ;-6^{\circ}\right]$ it is considered a leveled baseline, an ascending baseline, and within $\left[+6^{\circ} ;+31^{\circ}\right]$ it is considered a descending baseline.

\subsection{Simulation of Handwriting Samples}

The basic idea of proposing handwriting analysis is to facilitate the task of identifying and recognizing people with underlying aggression and violent behavior in their personality. These hidden signs lead them to do crimes and are associated with some types of personality disorders. One of the personality disorders named psychopathy has been studied by [63] based on their speech samples. Same pattern has been studied in [64] by doing social media service analysis. Here the handwriting aspect has been taken into consideration to study violent behavior. Forensic psychologists and graphologists have to go through tedious process of analyzing psychopaths' behaviors and handwritten documents. This part evaluates the handwriting samples of psychopaths and violent people. Due to sensitivity and scarcity of data in this domain we have gathered publicly available handwriting samples from graphology community[52] and from authenticated graphologist who study handwritings of personality disordered people, serial killers and anti-social people.

The original image is read from the location (Figure. 4.) and then it is pre-processed. Pre-processing includes grey-scaling the image, applying threshold and making it high contrast (Figure. 5). The main technique for finding the baseline slant in the handwritten text polygonization technique is used and 
it resulted in the closed polygon around one of the lines of the handwritten text. By using the coordinates of the polygon, slope is found as the slant of the baseline is indicated by the slope. Pen pressure is calculated by converting the image into a binary image. To achieve this a thresholding algorithm is used. The eyelevel pixel values in the handwritten image is mapped with a particular threshold. If it is below threshold it is mapped to pure (foreground) black and if it is above the threshold it mapped to (background)pure white. Grey level histogram is used to determine the threshold value. Pen-pressure is calculated by the threshold value. The higher values indicated light pressure. Number of foreground pixels is counted by number of black pixels in the threshold image. The number of black pixels indicates size of writing, thickness of strokes and the pen-pressure. Contours of texts are detected from the image and size of letters are calculated. These contours are plotted as rectangles on the image (Refer to Figure. 6.). Once these contours bounding the words of the text are highlighted, height is calculated and averaged over the height of all the contours. We extracted features like upper, middle and lower zone size, left and mixed slant, lowercase letter size, letter connectivity, loops in ovals and pressure of the handwriting sample.

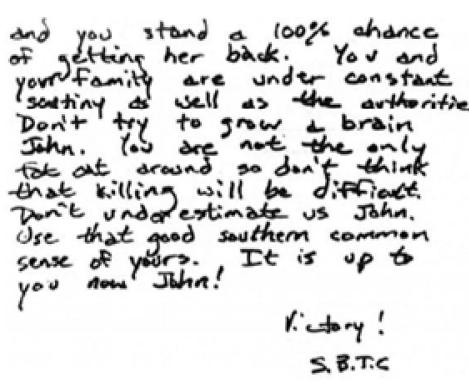

Figure 4:. Original Image

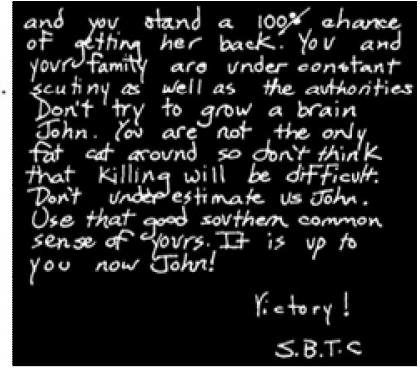

Figure 5: Image after preprocessing

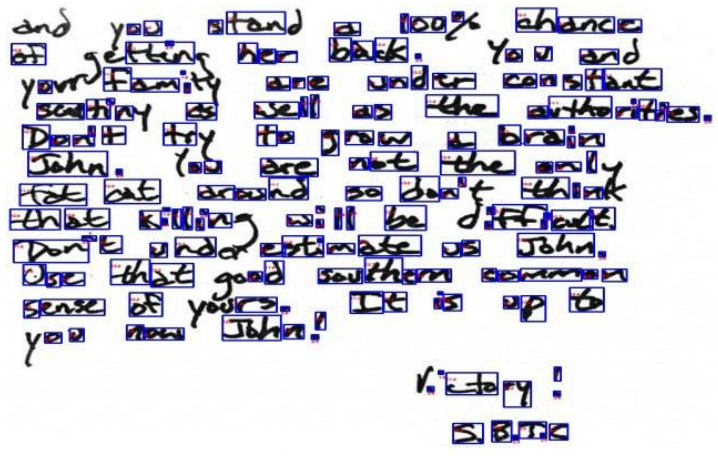

Figure 6: Image after contour plot

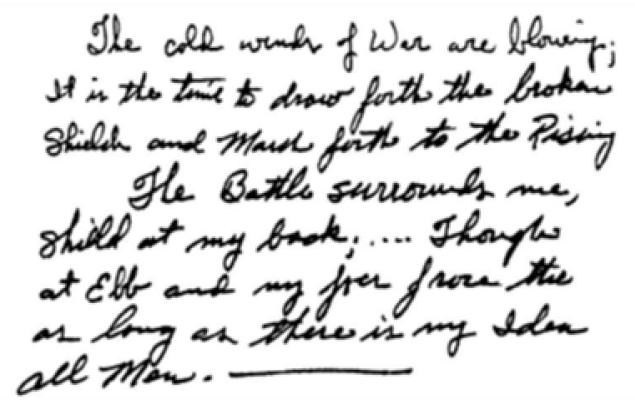

Figure 7: Violent handwriting sample image [12]



Figure 8: Violent handwriting sample

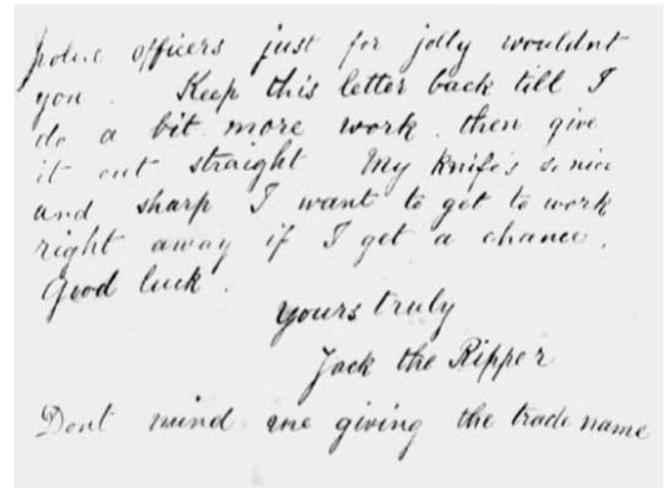

Figure 9: Violent handwriting

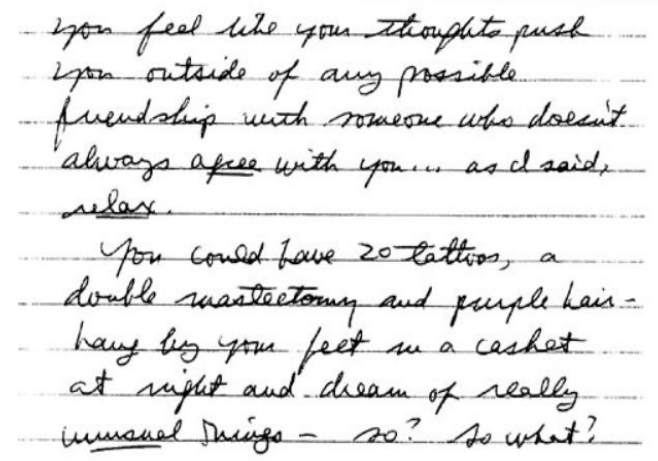

Figure 10: Violent handwriting 


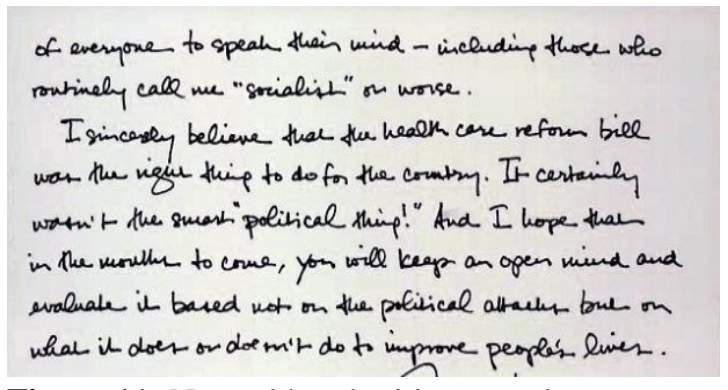

Figure 11: Normal handwriting sample

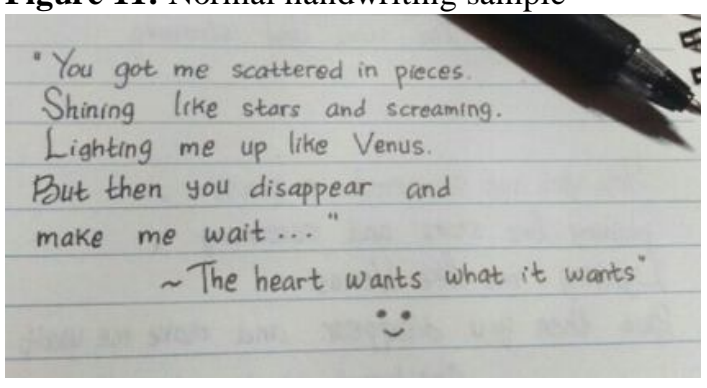

Figure 12: Normal handwriting sample

\subsubsection{Simulation Results}

Above are some samples of processed images of violent and normal handwriting samples. These images and cleaned and processed to find graphical features in handwriting. Various features are calculated and results are formalized in Table 4.

Table 4: Features extracted in handwritten image

\begin{tabular}{|c|c|c|c|c|c|c|}
\hline \multirow[b]{2}{*}{$\begin{array}{l}\text { Graphical } \\
\text { Properties }\end{array}$} & \multicolumn{3}{|c|}{$\begin{array}{l}\text { Violent/ aggressive } \\
\text { features }\end{array}$} & \multicolumn{3}{|c|}{$\begin{array}{l}\text { Normal handwriting } \\
\text { features }\end{array}$} \\
\hline & $\begin{array}{l}\text { Min( } \\
\text { mm) }\end{array}$ & $\begin{array}{l}\text { Max }( \\
\text { mm) }\end{array}$ & $\begin{array}{l}\text { Mean } \\
(\mathbf{m m})\end{array}$ & $\begin{array}{l}\text { Min( } \\
\text { mm) }\end{array}$ & $\begin{array}{l}\text { Whax }( \\
\text { mmm) }\end{array}$ & $\begin{array}{l}\text { Whang } \\
\text { (mm) }\end{array}$ \\
\hline $\begin{array}{l}\text { Upper zone } \\
\text { size }\end{array}$ & 1.2 & 6.88 & 1.3 & 1.01 & 5.02 & 0.8 \\
\hline $\begin{array}{l}\text { Middle zone } \\
\text { size }\end{array}$ & 1.20 & 2.65 & 1.2 & 1.2 & 1.07 & 1.12 \\
\hline $\begin{array}{l}\text { Lower zone } \\
\text { size }\end{array}$ & 0.8 & 0.9 & 0.8 & 0.7 & 0.8 & 0.9 \\
\hline $\begin{array}{l}\text { Avg height } \\
\text { contour }\end{array}$ & 1.59 & 15.23 & 8.4 & 1.61 & 9.01 & 5.3 \\
\hline Left Slant & 1.5 & 13.1 & 16.1 & 1.4 & 9.02 & 15.2 \\
\hline Mixed Slant & 1.5 & 12.1 & 19.3 & 1.5 & 9.32 & 20.1 \\
\hline $\begin{array}{l}\text { Lower zone } \\
\text { size }\end{array}$ & 1.21 & 4.31 & 0.8 & 1.23 & 5.12 & 0.9 \\
\hline $\begin{array}{l}\text { Medium zone } \\
\text { size }\end{array}$ & 1.22 & 5.02 & 1.3 & 1.3 & 8.05 & 1.2 \\
\hline Upper zone size & 1.21 & 13.21 & 1.2 & 1.21 & 9.3 & 0.8 \\
\hline Line Horizontal & 1.12 & 12.23 & 11.7 & 1.02 & 8.34 & 12.5 \\
\hline $\begin{array}{l}\text { Line } \\
\text { Descending }\end{array}$ & 1.12 & 9.02 & 2.9 & 1.12 & 7.02 & 2.5 \\
\hline $\begin{array}{l}\text { Letter } \\
\text { Connectivity }\end{array}$ & 1.32 & 6.82 & 16.8 & 1.2 & 4.3 & 17.0 \\
\hline $\begin{array}{l}\text { Phrase } \\
\text { Connectivity }\end{array}$ & 1.1 & 1.07 & 1.1 & 1.02 & 2.09 & 1.2 \\
\hline $\begin{array}{l}\text { Intense } \\
\text { handwriting } \\
\text { pressure }\end{array}$ & 12.1 & 32.2 & 23.1 & 8.6 & 21.2 & 21.9 \\
\hline $\begin{array}{l}\text { Loops in } \\
\text { writing ovals }\end{array}$ & 11.3 & 12.2 & 14.7 & 4.3 & 7.2 & 8.7 \\
\hline
\end{tabular}

As we can see the size of lower zone is 0.8 and size of upper zone is 6.88 on average for the processed images. It has been observed that average height of contours is 8.41 which is considered to be much larger than handwriting of an average person. Along with this some letters drop below baseline which is considered to be sign of dangerousness. The supporting facts are depicted in Figure 2 and Table 3. As discussed in the literate above while writing ovals violent people tend to make loops. Table 6. predicts tendency of violence in handwriting as its maximum value is found to be on higher side i.e. $14.7 \mathrm{~mm}$. Some handwriting samples were showing greater left slant which represents distorted handwriting along with signs of anxiety and violence $[49,50]$. While processing handwriting samples we observed intense pressure in some of the handwriting samples thus able to support and predict facts presented in Fig 2. Intense pressure is sign of dangerousness. Max value of intense pressure reported was 23.1. Below are the graphical presentations of the tabular data which presents facts in a unique way.

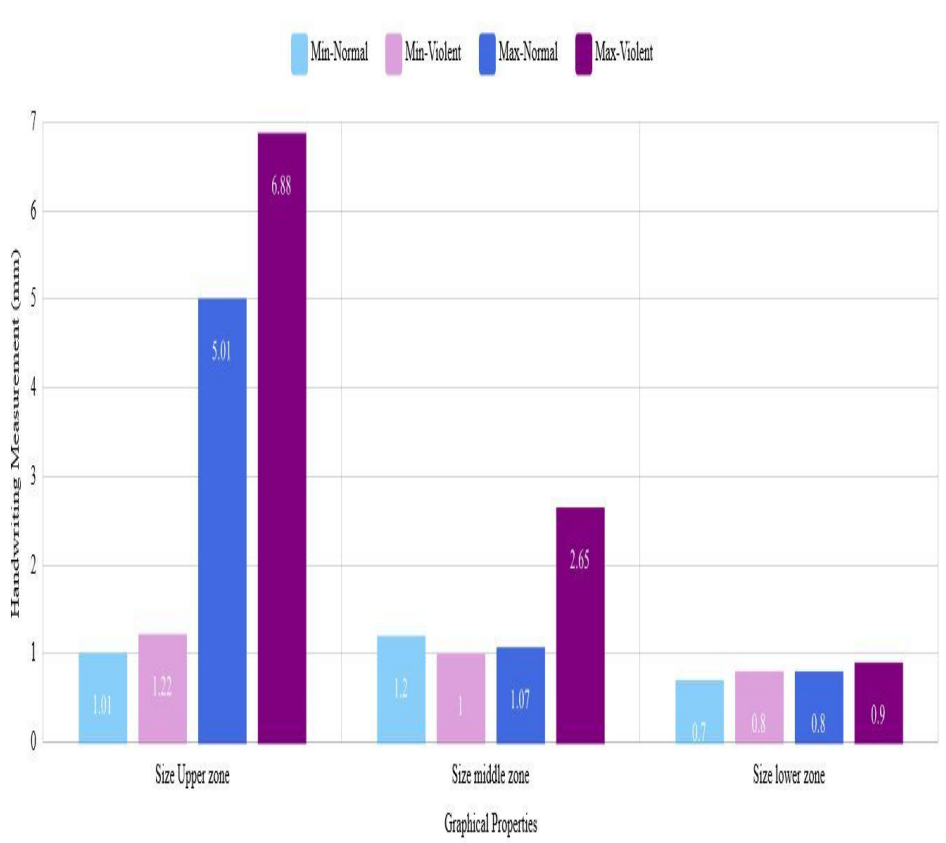

Figure 13: Upper, lower and middle zone handwriting features 




Figure 14: Avg contour height, left and mixed slant handwriting features

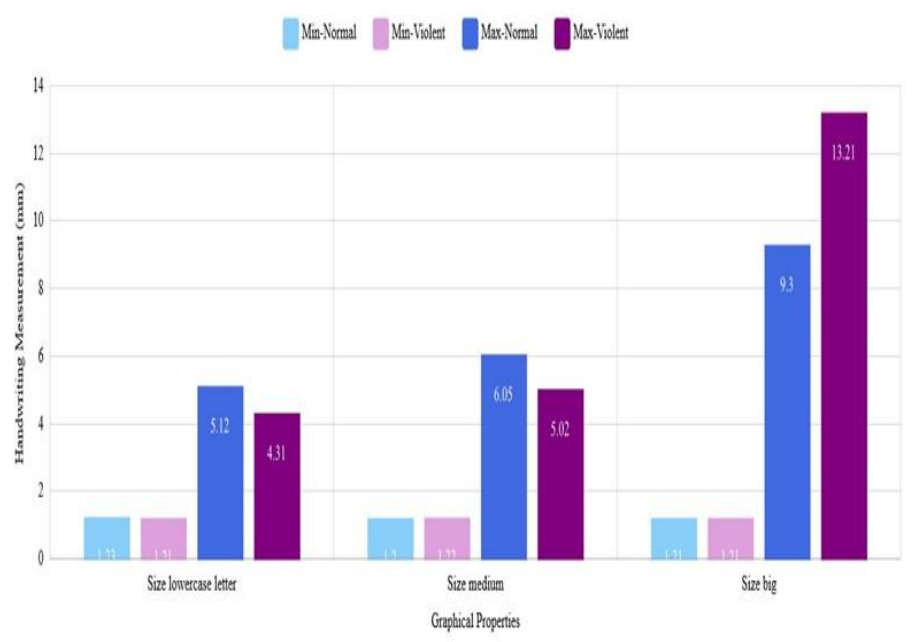

Figure.15: Lowercase letter size, medium and big size handwriting features

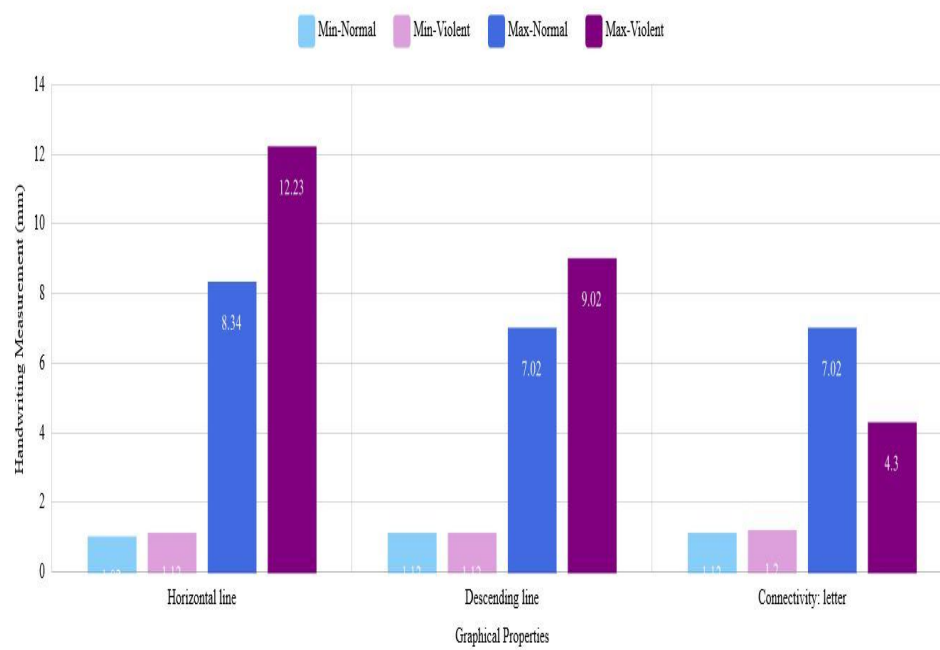

Figure 16.:Horizontal line, Descending line and letter connectivity handwriting feature

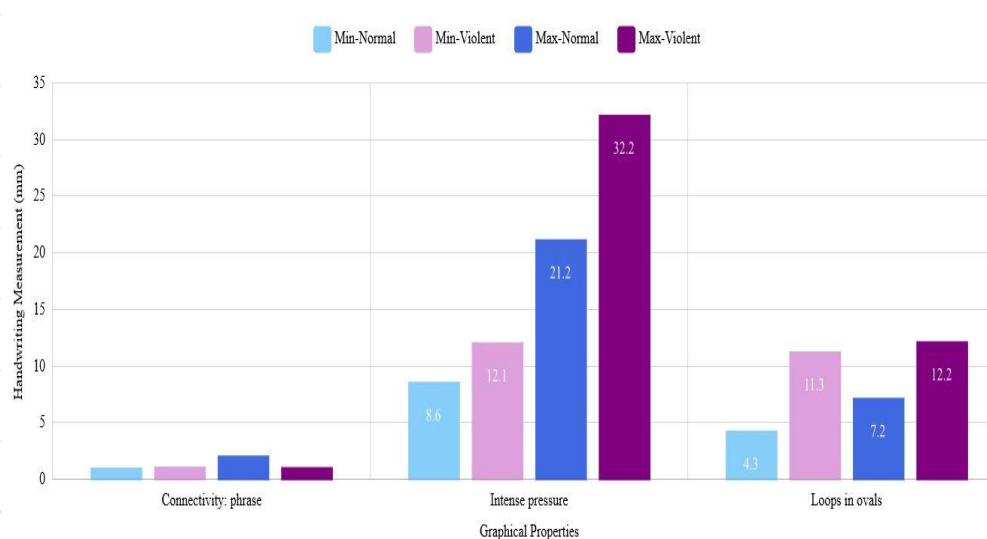

Figure 17: Connectivity phrase, intense pressure and loops in ovals handwriting features.

Above figures show the features comparison of violent and normal handwriting samples. In Figure 13 we have compared Lower, middle and upper zones in violent and normal handwriting. Light blue color represents the min value in normal handwriting and light purple color shows min value of violent handwriting sample. Dark blue color on graph shows the maximum value of upper, middle and lower zones of normal handwriting sample whereas dark purple color presents the max value of upper, middle and lower zones of violent handwriting sample. Fig. 13 clearly shows violent handwriting zones are larger than the normal handwriting thus we can say that people having violence likely to write big letters when compared with normal ones. Fig. 14 shows the predictability left and mixed slant feature in the handwriting of violent people and normal people. From the chart, it was observed that violent people tend to use different types of slant in their single handwriting sample. More left and more mixed slant was found while analyzing their handwriting whereas people with normal handwriting sample tend to use either left or right slant throughout their handwriting. People with violent handwriting sample were not consistent in using slant in their handwriting. On the other hand, Fig. 15 show some unique results, as we can see size of lowercase letter in violent handwriting sample is much less as compared to normal handwriting sample as size of lowercase letter in violent handwriting sample is 4.31 which is less as compared to value in normal handwriting sample which is 5.21, moreover medium zone letter size is also presenting the same fact. Size of letter in medium zone is 5.02 which is less as compared to value 6.05 in normal handwriting sample. The variations compared with normal handwriting samples shows the possibility of uneven letter formations in violent handwriting sample. Some surprising results were also part of the current research. There was no letter connectivity in the violent handwriting sample as it can be seen in Fig 16. Its value is 4.03 which was much less than 7.02 value of normal 
handwriting sample. Phrase connectivity was also missing in violent handwriting sample and because of its low value it is not visible as can be seen in Figure 17. Intense pressure and more loops were more prominent in the violent handwriting sample as compared to normal handwriting sample.

\section{DISCUSSION, LIMITATIONS AND FUTURE SCOPE}

In this paper violent behavior tendencies and dangerousness in one's personality has been studied from handwriting analysis. By retrieving features like height from contours, connectivity, loops, slant and size of the upper zone from the handwriting samples, satisfactory results were obtained to identify red flags in handwriting sample. However, this this method has some limitations. First, some prominent features have been taken into account to see signs of violence and dangerousness in handwriting sample. Second limitation is that these features were identified from a small set of violent handwriting data due to security concerns, thus has potential to extend further research from a much larger dataset of violent handwriting data. Along with this number of features can be increased for better results. In this analysis features like formation of each alphabet, formation of ' $y$ ' and its different looping styles have not taken into consideration. Due to the extensive nature of graphology and its vast areas, identifying violence in one's personality is highly challenging. For that some more red flags like distorted angles, letter " $\mathrm{t}$ " and " $\mathrm{f}$ " and more features should be included. This work can be extended by studying extensive set of features and certain patterns can be discovered with the help of machine learning algorithm. Thus, it can become useful tool in identifying violent features in handwriting thus may be helpful in identifying signs of violence in one's personality.

A conclusion section is not required. Although a conclusion may review the main points of the paper, do not replicate the abstract as the conclusion. A conclusion might elaborate on the importance of the work or suggest applications and extensions.

\section{REFERENCES}

1. T. Article, "nirbhaya case," 2019..

2. Indiatoday, "ryan school murder case," vol. 8, no. 9.

3. outlook, "Devil in flesh."

4. R. Hare, "psychopathy list," vol. 53, no. 9.

5. S. Lambe, C. Hamilton-Giachritsis, E. Garner, and J. Walker, "The Role of Narcissism in Aggression and Violence: A Systematic Review," Trauma, Violence, Abus., vol. 19, no. 2, pp. 209-230, 2018, doi: $10.1177 / 1524838016650190$.

6. D. Gallardo-Pujol and N. Pereda, "Person-environment transactions: persionality traits moderate and mediate the effects," Personal. Ment. Health, vol. 7, no. April 2012, pp. 102-113, 2013, doi: 10.1002/pmh.

7. R. Howard, "Personality disorders and violence: what is the link?," Borderline Personal. Disord. Emot. Dysregulation, vol. 2, no. 1, pp. 1-11, 2015, doi: 10.1186/s40479-015-0033-x.

8. R. Yu, J. R. Geddes, and S. Fazel, "Personality disorders, violence, and antisocial behavior: A systematic review and meta-regresion analysis," J. Pers. Disord., vol. 26, no. 5, pp. 775-792, 2012, doi: 10.1521/pedi.2012.26.5.775.

9. A. Rehman, S. Naz, and M. I. Razzak, "Writer identification using machine learning approaches: a comprehensive review," Multimed. Tools Appl., vol. 78, no. 8, pp. 10889-10931, Apr. 2019, doi: 10.1007/s11042-018-6577-1.

10. G. Luria, A. Kahana, and S. Rosenblum, "Detection of Deception Via Handwriting Behaviors Using a Computerized Tool: Toward an Evaluation of Malingering," Cognit. Comput., vol. 6, no. 4, pp. 849-855, 2014, doi: 10.1007/s12559-014-9288-6.

11. K. Amend and M. S. Ruiz, Handwriting Analysis The Complete Basic Book. 1980.

12. D. J. Antony, "Personality Profile Through Handwriting Analysis," pp. 1-118, 2008.

13. R. Plamondon, "Neuromuscular Studies of Handwriting Generation and Representation," pp. 261-261, 2011, doi: 10.1109/icfhr.2010.129.

14. L. Guarnera et al., "Forensic analysis of handwritten documents with GRAPHJ," J. Electron. Imaging, vol. 27, no. 05, p. 1, 2018, doi: 10.1117/1.jei.27.5.051230.

15. S. Aguilar-Ortiz et al., "Abnormalities in gray matter volume in patients with borderline personality disorder and their relation to lifetime depression: A VBM study," PLoS One, vol. 13, no. 2, pp. 1-14, 2018, doi: 10.1371/journal.pone.0191946.

16. G. H. Singh, R. J. Mehta, N. D. Shah, and R. Y. Mehta, "Handwriting Change as a Psychiatric Symptom," Int. J. Med. Dent. Sci., vol. 5, no. 1, p. 1075, 2016, doi: 10.19056/ijmdsjssmes/2016/v5i1/83579.

17. B. Identification, C. N. Networks, D. Examination, and Q. Documents, Behavioral Identification based on Heterogeneous Handwritten Aided by Deep Learning on a Novel Standard Dataset. .

18. L. Guarnera et al., "GRAPHJ: A Forensics Tool for Handwriting Analysis," Lect. Notes Comput. Sci. (including Subser. Lect. Notes Artif. Intell. Lect. Notes Bioinformatics), vol. 10485 LNCS, pp. 591-601, 2017, doi: 10.1007/978-3-319-68548-9_54.

19. C. Iulia, "The Writings of criminal minds criminilogy and handwriting analysis". Crineanu Iulia forensic expert, România," vol. 1, no. 4, pp. 163-175, 1962.

20. P. Joshi, P. Ghaskadbi, and S. Tendulkar, "A machine learning approach to employability evaluation using handwriting analysis," in Communications in Computer and Information Science, 2019, vol. 955, pp. 253-263, doi: 10.1007/978-981-13-3140-4_23. 
21. H. Hemlata, M. Manoj, and S. Kumar, "Personality Detection using Handwriting Analysis Review," pp. 85-89, 2018, doi: 10.15224/978-1-63248-157-3-33.

22. P. Joshi, A. Agarwal, A. Dhavale, R. Suryavanshi, and S. Kodolikar, "Handwriting Analysis for Detection of Personality Traits using Machine Learning Approach," Int. J. Comput. Appl., vol. 130, no. 15, pp. 40-45, 2015, doi: 10.5120/ijca2015907189.

23. A. H. Garoot, M. Safar, and C. Y. Suen, "A Comprehensive Survey on Handwriting and Computerized Graphology," in Proceedings of the International Conference on Document Analysis and Recognition, ICDAR, 2017, vol. 1, pp. 621-626, doi: 10.1109/ICDAR.2017.107.

24. R. Ben Abdessalem and N. Tabbane, Proceedings of International Conference on Wireless Communication, vol. 19. Springer Singapore, 2018.

25. P. B. Dasgupta, "Human Behavioral Analysis Based on Handwriting Recognition and Text Processing," Int. J. Comput. Trends Technol., vol. 64, no. 1, pp. 1-4, 2018, doi: 10.14445/22312803/ijctt-v64p101.

26. A. Bandyopadhyay, B. Mukherjee, and A. Hazra, "Perception Based Decision Support System for Handwriting Behaviour Analysis," Procedia Comput. Sci., vol. 84, pp. 177-185, 2016, doi: 10.1016/j.procs.2016.04.084.

27. D. S. D. Syeda Asra1 and 1Department, "Identification of Personality Trait by Handwriting Analysis Using SVM Classifier," vol. 5, no. 11, p. 9, 2017.

28. B. Fallah and H. Khotanlou, "Detecting features of human personality based on handwriting using learning algorithms," Adv. Comput. Sci. an Int. J., vol. 4, no. 6, pp. 31-37, 2015 .

29. V. Sharma and E. Depti, "Human Behavior Prediction," Int. J. Adv. Res. Electron. Commun. Eng., vol. 6, no. 2, pp. 57-62, 2017.

30. K. N. Lakshmi, A. Keerthana, and P. R. Lakshmi, "Handwriting Analysis Based Human Personality Prediction Using Sugeno Fuzzy Model," Int. J. Sci. Eng. Res., vol. 8, no. 5, pp. 105-110, 2017.

31. M. DAVID R. DIDUCH, MD, and KORNELIS A. POELSTRA and Since, "Handwritten Text Recognition using Deep Learning," Oper. Tech. Sports Med., vol. 9, no. 3, pp. 176-182, 2003, doi: $10.1053 /$ otsm.

32. C. Adak, B. B. Chaudhuri, and M. Blumenstein, "An empirical study on writer identification and verification from intra-variable individual handwriting," IEEE Access, vol. 7, no. c, pp. 24738-24758, 2019, doi: 10.1109/ACCESS.2019.2899908.

33. J. Fisher, A. Maredia, A. Nixon, N. Williams, and J. Leet, "Identifying Personality Traits, and Especially Traits Resulting in Violent Behavior through Automatic Handwriting Analysis," Csis.Pace.Edu, pp. $1-8,2012$.
34. A. Kathait and A. Singh, "Automated Prediction of Human Behavior System for Career Counselling of an Individual through Handwriting Analysis /," vol. 12, no. December, pp. 1-25, 2014.

35. I. Journal and O. F. Engineering, "International journal of engineering sciences and research technology" Human Character Recognition by Handwriting using Fuzzy Logic" *1,2," vol. 3, no. 6, 2014.

36. A. Chahi, Y. El Merabet, Y. Ruichek, and R. Touahni, "Off-line text-independent writer identification using local convex micro-structure patterns," ACM Int. Conf. Proceeding Ser., pp. 1-5, 2019, doi: 10.1145/3314074.3314080.

37. S. Asra and S. D.C, "Personality Trait Identification Using Unconstrained Cursive and Mood Invariant Handwritten Text," Int. J. Educ. Manag. Eng., vol. 5, no. 5, pp. 20-31, 2015, doi: 10.5815/ijeme.2015.05.03.

38. M. E. Johnson, T. W. Vastrick, M. Boulanger, and E. Schuetzner, "Measuring the Frequency Occurrence of Handwriting and Handprinting Characteristics," J. Forensic Sci., vol. 62, no. 1, pp. 142-163, 2017, doi: 10.1111/1556-4029.13248.

39. G. R. Ball and S. N. Srihari, "Statistical characterization of handwriting characteristics using automated tools," Doc. Recognit. Retr. XVIII, vol. 7874, p. 78740H, 2011, doi: 10.1117/12.876536.

40. T. L. P. Tang, "Detecting Honest People's Lies in Handwriting: The Power of the Ten Commandments and Internalized Ethical Values," J. Bus. Ethics, vol. 106, no. 4, pp. 389-400, 2012, doi: 10.1007/s10551-011-1015-6.

41. S. N. Srihari, S.-H. Cha, H. Arora, and S. Lee, "Individuality of Handwriting," J. Forensic Sci., vol. 47, no. 4, p. 15447J, 2002, doi: 10.1520/jfs15447j.

42. M. Gavrilescu and N. Vizireanu, "Predicting the Big Five personality traits from handwriting," Eurasip J. Image Video Process., vol. 2018, no. 1, Dec. 2018, doi: 10.1186/s13640-018-0297-3.

43. B. Gawda, "Lack of evidence for the assessment of personality traits using handwriting analysis," Polish Psychol. Bull., vol. 45, no. 1, pp. 73-79, 2014, doi: 10.2478/ppb-2014-0011.

44. B. Gawda, "The computational analyses of handwriting in individuals with psychopathic personality disorder," PLoS One, vol. 14, no. 12, pp. 1-14, 2019, doi: 10.1371/journal.pone.0225182.

45. B. F. Skinner, "A Behavioral Model of Creation," Creat. Quest., vol. 00, no. December 2008, pp. 267-273, 1976.

46. H. N. Champa and K. R. AnandaKumar, "Automated human behavior prediction through handwriting analysis," Proc. - 1st Int. Conf. Integr. Intell. Comput. ICIIC 2010, pp. 160-165, 2010, doi: 10.1109/ICIIC.2010.29.

47. R. N. M. Ron Morris, Forensic Handwriting Identification: Fundamental Concepts and Principles. . 
48. C. Rush and D. Ph, "Forensic Document Examination Fraudulent Documents What is a Handwriting Expert?"

49. P. E. CRONJE, "thesis," 2009.

50. I. Marcuse, Guide to Personality Through Your Handwriting Paperback - 1971. .

51. H. E. S. Said, K. D. Baker, and T. N. Tan, "Personal identification based on handwriting," vol. 33, pp. 1761-1764, 2002, doi: 10.1109/icpr.1998.712068.

52. H. Y. Kueh, E. Marco, M. Springer, S. Sivaramakrishnan, and D. Images, "Image analysis for biology - Cross-correlation,” pp. 1-52, 2008.

53. W. L. Lee and K. C. Fan, "Document image preprocessing based on optimal Boolean filters," Signal Processing, vol. 80, no. 1, pp. 45-55, 2000, doi: 10.1016/S0165-1684(99)00110-3.

54. A. Suliman, "Chain Coding and Pre Processing Stages of Handwritten Character Image File," J. Comput. Sci., vol. 2, no. 1, pp. 6-13, 2010.

55. Z. Mortezaie, H. Hassanpour, and S. A. Amiri, "Contrast Enhancement in Digital Images Using an Adaptive Unsharp Masking Method," vol. 11, no. 9, pp. 1051-1056, 2017.

56. B. Gawda, "Dysfluent handwriting in schizophrenic outpatients," Percept. Mot. Skills, vol. 122, no. 2, pp. 560-577, Apr. 2016, doi: 10.1177/0031512516637019.

57. Y. Solihin and C. G. Leedham, "Integral ratio: A new class of global thresholding techniques for handwriting images," IEEE Trans. Pattern Anal. Mach. Intell., vol. 21, no. 8, pp. 761-768, 1999, doi: $10.1109 / 34.784289$.

58. K. Chen, F. Yin, and C. L. Liu, "Hybrid page segmentation with efficient whitespace rectangles extraction and grouping," Proc. Int. Conf. Doc. Anal. Recognition, ICDAR, pp. 958-962, 2013, doi: 10.1109/ICDAR.2013.194.

59. R. Legault and C. Y. Suen, "Optimal local weighted averaging methods in contour smoothing," IEEE Trans. Pattern Anal. Mach. Intell., vol. 19, no. 8, pp. 801-817, 1997, doi: 10.1109/34.608276.

60. M. B. Menhaj and F. Razzazi, “A new fuzzy character segmentation algorithm for persian / arabic typed texts," Lect. Notes Comput. Sci. (including Subser. Lect. Notes Artif. Intell. Lect. Notes Bioinformatics), vol. 1625, no. 424, pp. 151-158, 1999, doi: 10.1007/3-540-48774-3_18.

61. "Handwriting-L, For the Graphology Community." [Online]. Available:

http://www.handwriting.org/desperados.html.

62. S. N. Srihari, S. H. Cha, and S. Lee, "Establishing Handwriting individuality using pattern recognition techniques," Proc. Int. Conf. Doc. Anal. Recognition, ICDAR, vol. 2001-Janua, no. i, pp. 1195-1204, 2001, doi: 10.1109/ICDAR.2001.953974.

63. D. Jain, S. Arora, and C. K. Jha, "Diagnosis of Psychopathic Personality Disorder with Speech
Patterns," Commun. Comput. Inf. Sci., vol. 1075, pp. 411-421, 2019, doi: 10.1007/978-981-15-0108-1_38.

64. Ummu Hani’ Hair Zaki1, Roliana Ibrahim2, Shaliza Abd Halim3, "A Social Media Services Analysis" International Journal of Advanced Trends in Computer Science and Engineering, Vol 8. No. 1.6, 2019 https://doi.org/10.30534/ijatcse/2019/1181.62019

65. Hamidah Jantan, Aina Zalikha Mohd Jamil, "Association Rule Mining Based Crime Analysis using Apriori Algorithm", International Journal of Advanced Trends in Computer Science and Engineering, Volume 8, No.1.5, 2019. https://doi.org/10.30534/ijatcse/2019/0581.52019 